\title{
PAPOLA wt Allele
}

National Cancer Institute

\section{Source}

National Cancer Institute. PAPOLA wt Allele. NCI Thesaurus. Code C51335.

Human PAPOLA wild-type allele is located in the vicinity of $14 q 32.31$ and is approximately $65 \mathrm{~kb}$ in length. This allele, which encodes poly(A) polymerase alpha protein, is involved in both the synthesis of the $3^{\prime}$ poly(A) tail of mRNAs and endoribonucleolytic cleavage at some polyadenylation sites. 